Article

\title{
“No German, No Service": EU Migrants' Unequal Access to Welfare Entitlements in Germany
}

\author{
Nora Ratzmann ${ }^{1,2}$ \\ ${ }^{1}$ German Center for Migration and Integration Research, Germany; ratzmann@dezim-institut.de \\ ${ }^{2}$ Centre for Analysis of Social Exclusion, London School of Economics, UK
}

Submitted: 30 June 2021 | Accepted: 2 December 2021 | Published: 22 March 2022

\begin{abstract}
While existing research has analysed the intersecting migration and social security law, which stratifies migrants' formal social entitlements, less work has been done on the informal stratifications beyond the law that determine substantive social rights. This article illustrates the informal barriers to de facto benefit receipt that intra-EU migrant citizens may experience when claiming social assistance in local German job centres, regardless of their manifest legal entitlements. Focussing on informal, yet commonly institutionalised practices of language discrimination, analysis of 103 qualitative, in-depth interviews reveal recurring patterns of administrative exclusion beyond individual instances of discriminatory behaviour. The unwritten rules and everyday practices shaping administrators' claims-processing routines often go against what the law or administrative procedures proscribe, and could be considered as forms of discrimination. The former may be explained by institutional constraints, such as a performance-oriented management culture, legalistic claims-processing, or superficial diversity policies. By shedding light on how inequalities in access are constructed in daily administrative practice, this article adds to existing empirical knowledge on how informal inequalities in access emerge at different stages of the benefit claiming process, in contrast to formal social rights on paper, as well as social administrations' handling of diversity in a context of transnational social protection.
\end{abstract}

\section{Keywords}

discrimination; intra-EU migration; social administration; transnational social protection

\section{Issue}

This article is part of the issue "Transnational Social Protection: Inclusion for Whom? Theoretical Reflections and Migrant Experiences" edited by Elisabeth Scheibelhofer (University of Vienna), Emma Carmel (University of Bath), and Anna Amelina (University of Cottbus).

(C) 2022 by the author(s); licensee Cogitatio (Lisbon, Portugal). This article is licensed under a Creative Commons Attribution 4.0 International License (CC BY).

\section{Introduction}

Interactions with the state bureaucracy may be an unfamiliar, unsettling experience for those not accustomed to the local language and the intricate functioning of the host country's bureaucratic system. Being tasked with securing subsistence for the neediest population groups, German job centres are a good example of what clients may describe as a "faceless" bureaucracy. Benefit applicants and recipients often report feeling misunderstood. This includes migrant residents who can face experiences of discrimination when interacting with German employment administration, including job centres (Brussig et al.,
2017; Dittmar, 2016). However, I discovered through qualitative fieldwork that rather than being unwilling to support those in need, administrative staff commonly feel constrained by the institutional setting itself. Many appear to be dedicated caseworkers, wanting to improve the economic situation of some of the most vulnerable strata of society.

Shedding light onto the puzzle of perceived discrimination of claimants versus street-level bureaucrats' often benevolent attitude towards them, this article unravels some of the mechanisms by which administrative exclusion can occur. The analysis focuses on the diffuse and unwritten yet systematic rules, or in other 
words, everyday routines and practices of benefit claimsprocessing, rather than formally codified stratified social entitlements in law. The latter, legal exclusions from benefit receipt for different groups of European Union citizens, have been extensively covered elsewhere, for instance in the UK (Shutes, 2016; Shutes \& Walker, 2017). While not necessarily discriminatory in intent (Gomolla, 2010), such diffuse forms of discrimination through state agents foster practices of exclusion and systematic unequal treatment, and differential de facto (practical) access, between groups of social benefit claimants with equal legal entitlements. To uncover the institutional structures contributing to inequalities of opportunity in claims-processing, I analyse the barriers to de facto access, focusing on the angle of language discrimination that intra-EU migrant citizens may experience when engaging in local claims-making in German job centres - a group whose experiences tend to remain overlooked while now constituting one of the largest immigrant groups in Germany.

Broadly, this research finds that administrative processes of deciding on a social benefit claim are characterised by intricate patterns of de facto inclusion and exclusion at street-level, which can emerge through administrators handling of discretion. Many of these informally institutionalised, or unwritten, yet systematic practices of unequal treatment can be related either to the erroneous application of the law or the formal, legalistic application of the same rules to every benefit applicant and recipient. Administrative routines along with the institutional and political environment, which may carry a signalling effect into the policy implementation (Wright, 2011), can reinforce individual decisions around administrative inclusion or exclusion. My analysis specifically shows how instances of language discrimination against those claimants who are not fluent in German can translate into denial of their benefits claims at street-level. The findings contribute to the field by unravelling how street-level bureaucrats deal with claimant diversity when translating administrative guidelines into action, for instance justifying practices of de facto exclusion through meritocratic principles of procedural equal treatment.

\subsection{Methodological Note}

The findings presented here stem from a larger PhD research project on how administrative practices in local job centres construct inequalities in access to basic subsistence benefits (Ratzmann, 2019). The study builds on 103 in-depth, qualitative interviews lasting between 15 and 180 minutes each with (a) key informants, including policy-makers, specialised service providers performing social, and labour market integration services for the job centre, legal experts, migrant advisory and advocacy agencies (such as welfare organisations), totalling 32 interviews; (b) intra-EU migrant claimants (16 interviews); and (c) job centre staff (55 interviews; for a detailed breakdown of interviews see Ratzmann, 2019, appendix 3). The aim was to maximize variation in perspectives and voices to better understand the complex mechanisms of discrimination, including insights of those subjected to practices of administrative exclusion, of those shaping such practices, and of outsiders observing such daily implementation dynamics (for details see Ratzmann, 2019, pp. 85-88). The interviews were conducted in German and English, with a few exceptions of French-speaking respondents. The findings emerged from two main methods of qualitative data analysis, namely a closer interpretive reading of the interview scripts, and a relatively rigorous coding exercise. Transcripts were coded inductively after each round of fieldwork, using emergent themes instead of relying on a priori developed categories.

As regards feasibility, the study examined the implementation processes in a select number of cases in Berlin, choosing depth over breadth. Most interviews were carried out between June 2016 and July 2017 in Berlin, which is an interesting case as the biggest agglomeration with 3.6 million inhabitants. Berlin represents Germany's main migration hub, hosting three times more foreign nationals on its territory than the German average, who account for 19 percent of its population. Three Berlin-based job centres were selected as sub-cases to compare and contrast between institutionally similar locations (as all are administered jointly between the Federal Employment Agency and local government). I selected three institutions on the basis of their geographical location (taking into account the former East-West divide), their economic characteristics and their (migrant) claimant profiles. The aim was to achieve purposeful variance, inspired by Mill's (1843/2002) most different systems design. Considering the context of a qualitative study employing an interpretivist methodology, Mill's comparative case study method was loosely applied instead of starting out with a formal hypothesis. Potential hunches developed from the literature review served as a starting point, while I remained open to any analytical ideas emerging from the data in a grounded approach.

The study overall relied on the idea of contextdependent transferability across job centres of similar embeddedness (see Crotty, 1998). For that purpose, I triangulated emerging findings from the Berlin-based interviews with observational material from expert discussion fora and practitioners' meetings that bring together job centre representatives from various German regions (including expert meetings organised by the German Federal Ministry of Labour and Social Affairs, the German Chancellery, or round tables by civil society, such as the German welfare organisations; for details see Ratzmann, 2019 , appendix 3). The analysis suggested that local variation in job centres, whether concerning their geographical location or their (migrant) claimant profiles, did not seem to materially affect street-level bureaucrats' conduct and attitudes. Even though some variation in terms 
of magnitude may arise, the overall trend of seeking to complicate access for EU migrant groups appeared to persist across locations of similar embeddedness (i.e., in those local job centres jointly run by local governments and the Federal Employment Agency). As such, the findings presented here illustrate the informal processes that may lead to recurring instances of discrimination, but whether such practices are applied by the caseworker within a local job centre depends on the individual case.

\section{Conceptual Backdrop: Between Law and Implementation}

The EU upholds the principle of freedom of movement, thereby entitling its citizens to move to, reside mostly without restrictions, and work without a work permit or visa in another EU country. EU worker citizens involved in employment in a member state other than their own enjoy equal treatment with nationals in accessing employment and associated social advantages. With this may come a common pretence among EU and national policy-makers that EU migrant citizens living in another member state are treated as non-discriminated co-nationals. However, to what degree are these legal principles upheld in practice? To provide a backdrop, the first section sketches out the legal framework on intraEU migrant citizens' social rights. Then I discuss potential sources of discrimination that may arise during policy implementation from a conceptual point of view, taking into account the links to administrative discretion at street-level.

\subsection{Social Security: Entitlements and Regulations in Germany and the European Union}

In brief, the German social security system provides three forms of income support, namely a statutory, contribution-based unemployment benefit (UB I), a means-tested, tax-financed unemployment benefit (UB II) for jobseekers without sufficient contributions, and a social assistance benefit for citizens unable to work. As a legal baseline, EU citizens who are exercising rights of free movement are entitled to social benefits in Germany under the Freedom of Movement Law (FreizuegG/EU), which translated relevant European directives into German national law. During the initial three-month period, incoming EU citizens generally cannot claim any German social security benefits. After three months, social entitlements diverge: Economically inactive EU citizens are not eligible for any type of German social security benefit during their first five years of residence. In contrast, economically active EU citizens can receive German subsistence-securing benefits as income supplements to reach the social minimum (which is defined by the current UB II benefit level) if their income falls below that threshold and if they have contributed to German social security for at least six months prior to their spell of unemployment. On an operational level, EU Regulation 883/2004 on the EU social security coordination dictates that local welfare administrations should formally request social security contributions in a claimant's previous country of residence in order to establish eligibility.

Administrative guidelines specify how to process claims in practice. For instance, to initiate a benefit claim, the official procedures set out by the Federal Employment Agency envision a written response to any application independent of its prospects. Further provisions to get access to social benefits include a list of mandatory documents to provide for claims-processing, or when to apply sanctions (i.e., benefit cuts when claimants do not fulfil their duties). As for intra-EU migrant citizens, their entitlements include being provided with an interpreter at no cost by the respective job centre if they are unable to communicate in Germanbased on EU-Regulation 883/2004, which stipulates EU citizens' right to be served in their home country's language. The Federal Employment Agency Directive on Interpreting and Translating Services furthermore specifies that:

As part of the freedom of movement within the European Union, EU workers...without sufficient levels of German can avail themselves of services provided by the Federal Employment Agency. For this target group, access...should not be impeded by language barriers. All necessary interpreting and translating services should be provided. (Bundesagentur für Arbeit, 2011, p. 1, translation by the author)

Still, legal entitlements do not necessarily translate into the practice of de facto access to social benefits. Going beyond the legal stratifications of social entitlements, this article centres on the forms of discrimination that may arise when local administrators exercise discretion during local claims-processing, as discussed in the following section.

\subsection{Formal and Informal Expressions of Discrimination}

Discrimination commonly is defined as policies and actions that disadvantage some persons or social groups based on their membership in that group (Beigang et al., 2016). While the literature distinguishes between interpersonal, structural, discursive and institutional discrimination (Gomolla, 2010), this article focuses on the links between interpersonal and institutional discrimination. In this research, institutional discrimination can be understood as legal entitlements and institutional structures and procedures that may create inequalities in treatment. Such inequalities may lead to de facto unequal access to state-provided benefits and services. Considering the complexity of discrimination on legal, managerial and institutional levels, my analysis operationalises the concept through a focus on barriers to de facto benefit receipt and their underlying mechanisms. 
I analyse the actions and decisions of individuals as institutional representatives, which are shaped by the larger institutional framework and its functioning logics (Scharpf, 2000). The focus remains on the practices themselves, so the implementation dimension rather than the legal framework, which can closely relate to questions of fairness and social equality in a given society. Societal consensus of what is considered legitimate is commonly expressed in legal categories (Yanow \& van der Haar, 2013). Hence, the legal framework, and its operationalisation through administrative guidelines, serves as the yardstick against which I compare inequalities in treatment.

I found that discriminatory practices can emerge at different stages of claims-processing without discriminatory intent, for instance through legalistic equal treatment that disregards the diverse needs and circumstances of claimants. To systematise the characteristics of discriminatory treatment in local job centres, i.e., interpersonal, yet institutionally embedded discriminatory acts, I developed a matrix through inductive data analysis of my interviews and field notes (Figure 1).

The taxonomy of forms of discrimination is based on definitions from existing literature on discrimination (e.g., Gomolla, 2010), and these are elaborated through my qualitative data analysis to inductively develop their specific content as shaped through the workings of social administrations. As illustrated in Figure 1, the multi-level setting of EU and national law on the one hand, and rules of the institutions regarding principles of implementation on the other, creates room for administrative discretion. This discretion can then translate into inequalities in de facto benefit receipt or, in other words, different forms of discrimination for certain claimant groups. Generally, we can distinguish between direct and indirect, or hidden forms of discrimination (i.e., their degree of formalisation or institutionalisation on the horizontal axis).
Indirect discrimination happens when the same institutional rules and practices are applied to every benefit claimant, which might disadvantage some of them because of their characteristics. For instance, the Race Equality Directive (Council Directive of 29 June 2000, 2000) of the EU defines indirect discrimination as instances "where an apparently neutral provision, criterion or practice would put persons of a racial or ethnic origin at a particular disadvantage compared with other persons" (even though, based on the legitimate aim exception clause, there may be grounds to discriminate for objectively justifiable, proportionate reasons). Principles of formulaic equality fall in the realm of indirect discrimination, as equal treatment may lead to unequal outcomes. Moreover, a distinction between interpersonal and institutional discrimination is to be made (on the vertical axis). Interpersonal discrimination is related to discriminatory treatment of an individual based on his or her attitudes and subsequent behaviour, while institutional discrimination sheds light onto the institutional environment and its rules and procedures, in which the discriminatory strategies of action emerge as part of administrators' professional role (Gomolla \& Radtke, 2009).

\subsection{Characterising Street-level Implementation: Between Discretion and Informal Practices}

In the context of this research, discrimination often plays out in the form of informally institutionalised, patterned administrative practices of inclusion and exclusion from de facto access to social benefits and services. Such administrative practices may have an unequal impact on benefit applicants and recipients with equal legal entitlements. The informal side of discriminatory exclusion from, or unequal inclusion into, benefit receipt has been articulated in the street-level bureaucracy literature when studying administrative discretion but has received less attention in conceptual writings on discrimination.

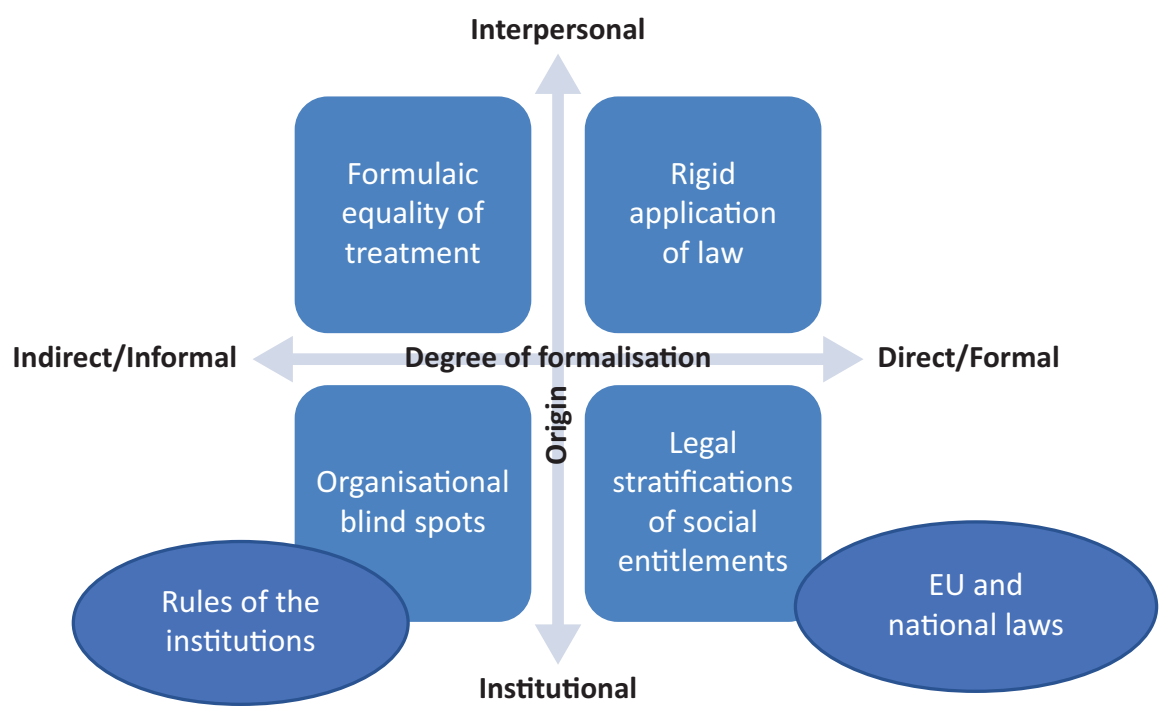

Figure 1. Characterising multi-level institutional discrimination in local job centres. 
In a nutshell, the respective literature describes street-level bureaucrats as those public service workers who interact directly with individual citizens in the course of their jobs, supplying claimants with often essential services that cannot be obtained elsewhere (Brodkin, 2013). Provision of subsistence-type benefits in German job centres constitutes a typical case of street-level work. Lipsky (1980), pioneering this body of scholarship, described the simplifying routines street-level bureaucrats rely on to deal with the pressure of policy implementation. Such coping strategies include people-processing techniques to manipulate caseloads, such as rationing and parking through use of waiting lists, rule adaptation, withholding of information, or creative rule interpretation for circumstances that had not been foreseen in the policy. Administrative burden commonly occurs as a side effect of such administrative coping strategies, but can also be deliberately imposed by social administrators to limit benefit and service receipt (Dubois, 2010). For instance, informal gate-keeping can emerge by imposing disproportionate and burdensome, hidden administrative costs that are not required by law, such as asking for additional documentation to process a case, or sharing information with some applicants but not others (Brodkin, 2013).

Related research further explored how local bureaucrats are far more than mere technocratic implementers of law and policy. Maynard-Moody and Musheno (2003), in an in-depth study of US police, teaching, and social administration, argued that bureaucrats use administrative discretion around following or bending rules based on the claimants' apparent deservingness to state support or lack thereof, rather than due to work pressure and routines shaping individual decisions. This body of research (e.g., Perna, 2018; Schweitzer, 2019), which stresses the politicised nature of discretionary claims processing, thereby focusing on administrators' value judgements regarding the claimants' circumstances. Here, administrators are understood as co-producers of normative value systems on the legitimacy of a claim made. For instance, Alpes and Spire (2014) in France, or Triandafyllidou (2003) in Italy, explained inconsistent decision-making by local migration authorities, in the form of case prioritisation, by administrators' ambition to protect cultural homogeneity. Therefore, it creates hidden borders to territorial access based on who administrators consider as belonging in the country. Analysing processes of inclusion and exclusion of EU migrant citizens in local job centres in the UK, Dwyer et al. (2019) alluded to issues of institutionalised welfare chauvinism, following a similar logic of excluding those not considered to belong.

The study of discretion is of interest once such informal strategies of inclusion and exclusion by local administrators develop into systematic routines (Brodkin, 2013). Differences in treatment can emerge because there is ample room for discretion built into the legal framework on social benefit receipt, to allow for the tailoring of measures specific to claimants' individual needs. While decisions on benefits access as such are not dis- cretionary, different ways of thinking about the benefit eligibility in German job centres indirectly open space for significant informal discretion (Heidenreich \& Rice, 2016). As a characteristic feature of service provision, discretion enables administrators to make a trade-off between efficiency, managerial pressure, and responsiveness to claimant needs. Moreover, procedural discretion can be exercised at several stages of the job-seeker's basic allowance claim, such as decisions about documentation required for processing a claim, the waiting times for processing a claim, or the application of sanctions once the benefit has been granted. As such, discretion refers to the flexible exercises of judgement and decisionmaking practised by public administrators, creating leeway for interpreting formal rules that affect the costs of claiming (Brodkin \& Majmundar, 2010).

Yet whether street-level bureaucrats exercise differential, and often discriminatory treatment, depends not solely on their attitude and willingness, but equally is shaped by institutional opportunities and constraints. For instance, some claimants are viewed as having, on average, some characteristics that might render their case challenging or costly to process-and hence incentivises parking techniques, which could be considered a form of unequal, and hence discriminatory treatment. Discrimination can also arise from a systematic lack of awareness for certain claimants' needs, or so-called organisational blind spots (Bach \& Wegrich, 2018). In other words, (in)formal discretion can open space for unequal treatment when processing benefit claims, which goes beyond erroneous interpretation of the legal and administrative framework. Primarily agencybased, such interpersonal forms of discrimination can be conditioned by institutional constraints, such as having little time to process legally complex and ambiguous cases like those of EU citizens, which could be interpreted as expressions of institutional discrimination.

The recurring practise of imposing German as the only language of communication in the claiming processes is the focus of this article. Such an administrative practice may turn intra-EU migrant citizens' social entitlements into a subject of discretionary deliberation instead of a pre-determined set of legal rights. In the context of benefit claims-processing, knowledge of the German language appears to serve as an informal vehicle to define the boundaries of membership in a community of solidarity, symbolically demarcating insiders and outsiders. As scholars (including Lamont \& Molnár, 2002) have demonstrated, such symbolic boundaries, functioning as social distinctions, could manifest themselves materially in the unequal distribution of resources. Local decisions on benefits access can translate into what qualifies as a case of boundary practice.

\section{EU Migrants' Unequal Claiming Experiences}

The interview sample reveals informal processes of excluding some intra-EU migrant applicants from access 
to benefits and associated labour market integration services but not others. Such inequalities in treatment may emerge during different stages of the claiming process, creating a series of hurdles (detailed in Ratzmann, 2019, pp. 100-114). Enforcing German as a language of communication appeared as a persistent practice across all stages, namely when initiating the claiming process, processing the application, and during the phase of benefit receipt.

In the following, I disentangle some of the informal expressions of agency-based discrimination, approaching it through the angle of language discrimination. The practices described here have been developed inductively from the interview data, following an interpretivist research approach (Soss, 2006), while triangulating them with findings of related research in Germany (Brussig et al., 2017; Dittmar, 2016), but also other EU countries, such as Austria (Holzinger, 2019; Scheibelhofer et al., 2021).

\subsection{Informal Expressions of Language Discrimination}

Overall, intra-EU migrant citizens in this study identified the insistence on German as the only language of communication with job centre staff as one of the key barriers to benefit and service receipt. As the data collected for this research indicate, EU foreign language claimants often felt discriminated against based on their inability to speak German, as this English-speaking interviewee studying for a PhD in Germany highlighted:

Sometimes I can speak English and they can understand. But from my experience, going through this process, more often than not, they will stop you and say: "No"...I just remember the language being a huge problem. (claimant interview 2 )

Several migrant interviewees perceived job centres' staff as unwilling to accommodate their limited language abilities in all phases of claim-processing (e.g., claimant interviews 5-7, 9, 10,17), being told to converse in the "official language, German" (Amtssprache Deutsch). In other words, if foreign-language applicants were not fluent in German when submitting their application or when attending appointments with their respective labour market advisors, they would not always be served in the same ways as those comfortable speaking the German language, as in the experience of the intra-EU citizens I interviewed (claimant interviews 1-6, 8-12, 18). Such a practice of denying claims on the basis of "no German, no service" (from my field notes, job centre Berlin) not only contradicts the EU Regulation 883/2004, which stipulates EU citizens' right to be served in their home country's language, but also the 2016 Federal Employment Agency Directive on interpreting and translating services. According to administrative protocol, intra-EU citizen claimants whose German skills are insufficiently developed to claim in German are entitled to an interpreter.
The field research further shows that not observing administrative protocol on language diversity could entail significant compounding effects. For instance, several key informant interviewees $(2,5,9,17,19,27)$, mostly from welfare organisations, revealed how job centre representatives may informally intercept claims without written justification as an informal gate-keeping technique. Effectively, several applicants in my study were denied the opportunity, and legal right, to submit a written benefit form to formally start the claiming process (claimant interviews 4, 6, 9, 10). Instead, their claim was rejected without the formal screening of their application, which could be qualified as interpersonal discrimination. I found that those applicants who could not fluently converse in German, appeared to be at risk of being turned away at job centres' entrance zone (e.g., claimant interview 6). As a French interviewee recalled, when she conveyed her difficulties of conversing in German to the receptionist at the local job centre she attended by saying: "Hello, I am non-German, but I can't speak German well, so I am speaking slowly." The response at reception simply was: "What a pity for you!" Such an answer led her to feel unwanted, of being perceived to be a "parasite," as she stated (claimant interview 10). Yet, as such practices tended to appear across job centres of different characteristics and locations, they could be seen as informally institutionalised. They did not appear to occur as isolated individual instances. Furthermore, a job centre in South-Western Germany even put up a sign at the reception, stating: "No service without an interpreter" (from field notes at practitioners' meetings), turning individual administrators' lack of responsiveness to foreign claimants' entitlements of and needs for translation into a formal practice of exclusion. My key informants consequently qualified language as an indirect instrument to regulate access to benefits and services in practice, burdening those claimants who were less equipped to fulfil these informal language requirements (e.g., key informant interview 9).

I found that similar dynamics of informal gatekeeping, especially when intra-EU migrants' felt unprepared, also characterised subsequent phases of claimsprocessing. Fieldwork showed that once intra-EU migrant citizens handed in their benefit application, many of them encountered less tangible barriers to accessing transnational social protection, including unnecessary administrative burdens that arose during the processing of their benefit application (claimant interviews 2, 4-7, 10-13, 18). For instance, the burden of proof for detailing previous social security provisions tended to be shifted to the claimants themselves, instead of local job centres relying on inter-agency cooperation and requesting this from the claimant's previous country of residency (e.g., key informant interview 2; field notes from civil society roundtables). Despite being envisioned through the European legal framework, transnational social security data exchange appeared to rarely happen in practice (also Scheibelhofer \& Holzinger, 2018). 
My EU migrant interviewees recounted how being tasked to provide such documentation themselves could discourage them to pursue a claim (claimant interviews $10,13,18)$, as foreign national bureaucracies tended to only issue such documents when requested in person. The procedure obliged intra-EU migrant applicants to travel home, engendering financial losses and significant time delays in processing the claim. EU applicants commonly also had to cover travel expenses and translation costs because local job centres may only accept such documentation when translated into German, even though costs ought to covered by German job centres themselves (key informant interview 2; field notes from civil society roundtables).

Another local-level practice that produced intangible costs to claiming was the request of additional documents not essential to claims-processing (key informant interviews 1, 9, 17, 26, 27): These had either ceased to exist (such as a registration certificate for EU citizens issued by the German Foreign Office) or were commonly difficult to obtain (e.g., deregistration certificates form their last country of residence; all notices of termination of employment within the last 15 years; vaccination certificates of their children, mirroring findings of a non-representative survey; also see BAGFW, 2021). In short, proof of eligibility, including the provision of documents translated into German, tended to be outsourced to the claimants rather than handled at the inter-agency level as foreseen by the administrative framework.

The described cumulative disadvantage could carry into the next phase of benefit receipt. The case of a Polish claimant I met during my shadowing activities exemplifies this process. When I observed the meeting at the local job centre, the first question asked of the claimant was whether she was able to speak German. When she answered "not very well," the immediate reaction of her labour market advisor was irritation about why she did not bring an interpreter. Subsequently, when they tried to fill in the application together, inconsistencies in the claimant's work history arose. The inconsistencies appeared to result from the claimant's inability to express herself in German. These inconsistencies nevertheless fuelled the suspicion and anger of the local administrator, who ended up concluding: "This all seems a bit strange, a bit dubious to me. I have a hard time believing you, I have to admit. I have to investigate." After the meeting, the administrator turned towards me, stating that "towards those who try to advance a pregnancy to circumvent the work requirement, [l am] always suspicious....As for Eastern Europeans, one has to investigate very carefully" (from field notes at a local job centre). In her manner of reasoning, the social administrator implicitly relied on the discriminatory trope of social tourism, whereby an intrinsic link between perceived illegitimate behaviour of welfare abuse and national belonging appears to be drawn (for details see Ratzmann, 2021).
During my fieldwork, I could observe other episodes of restrictive scrutiny of EU national claimants who were not very well-versed in German, for instance when a labour market advisor sanctioned another Polish claimant for not attending a job search coaching to which he had assigned him. He qualified his clients' behaviour as intentional non-compliance while the written correspondence with the benefit recipient I reviewed revealed very poor German language skills, suggesting that the recipient might not have understood the purpose of the training (from fields notes at a local job centre). The latter consideration may have called for some leniency in the use of administrative discretion, considering the lack of German knowledge, particularly when it comes to complex administrative language. This could have included spending more time on the claimant case, making sure the procedures have been correctly understood instead of rigidly and immediately sanctioning the benefit recipient.

The described instances illustrate how language remains not only a functional element of communication but can act as a signifier of legitimate belonging to the respective community of solidarity. As I explore elsewhere (Ratzmann, 2021), job centre staff often consider those deserving who can converse in German, and appear "German enough," hence who assimilated into the German host society. Social administrators' ideas of deservingness, of who they consider to be legitimate receivers of state-financed social support, tend to be conditioned by claimants' knowledge of the German language. The latter is taken as means to draw the (symbolic and material) boundaries between insiders and outsiders of de facto benefit recipients. In other words, street-level access to benefits can become linked to a "cultural conditionality" logic, whereby EU citizens are expected to demonstrate belonging through cultural markers such as language as proof of interest to integrate. Those with limited German knowledge remain barred from de facto access through the informal and formal strategies of exclusion from benefit receipt described above (for a similar argument based on the Austrian case see Holzinger, 2019).

Nevertheless, while patterns of informal exclusion through administrators' claims-processing can be discerned from the qualitative interview material, streetlevel bureaucrats should not be regarded as a homogenous group. Considering social administrators' scope for informal discretion during policy implementation, some sought to relax the imposition of the language-related administrative burden (from field notes at a local job centre). They demonstrate adaptation to EU citizens' language abilities whenever possible, as this labour market administrator (bureaucrat interview 21) explained:

I try really hard. I repeat. I try to simplify sentences or sometimes I write things down, on a piece of paper: Please go to local authority. Get document. So that the message passes. I also rely on gestures and mimics. 
Strategies included resorting to written notes that applicants could take with them to have translated elsewhere, and to English or using simplified German words and sentences (bureaucrat interviews 7, 8, 10, 26, 35). Such strategies could help to break down the complexity of administrative procedures, as, for example, official letters and documents could be up to 160 pages long and written in complex legal language. The awareness of immigrants' needs as newcomers described here, and willingness to accommodate them, often related to social bureaucrats' personal intercultural experiences or their own family history if characterised by immigration (Ratzmann, 2019, pp. 190-192).

The next section explores how various patterns of informal administrative inclusion into, or exclusion from, de facto benefit receipt may occur during discretionary claims-processing. It uncovers some of the underlying mechanisms, including the unawareness of EU migrants' complex legal entitlements or their needs as newcomers to German society and bureaucracy, that serve as organisational blind spots and thereby engender (institutional) discrimination.

\subsection{Explaining Intra-EU Migrants' Local Claiming Experiences}

As postulated above, ideas about belonging and deservingness may shape de facto access to benefits and services, based on "appearing German enough," or in other words, cultural assimilation. My findings suggest that discriminatory attitudes towards claimants with limited German language ability can be present among job centre representatives (e.g., bureaucrat interviews 10, 32, $41,46,51)$. When advancing their individual reasoning, some interviewees would draw a link between claimants' German language skills and their perceptions of what constitutes legitimate access to state-financed social benefits and services. As both a labour market advisor and a benefits clerk exemplarily suggested (field notes at a local job centre; bureaucrat interview 41), they considered language skills as a prerequisite to legitimate benefit receipt:

Often they don't speak the language, but they tend to know how to get access. I find that bit annoying.

Problematic are foreigners who don't speak German....They are too lazy to understand the official letters.

Such a finding typifies the dominating paradigm of German migrant integration policy, which builds on the implicit assumption that immigrants are transient guests that remain "othered outsiders" until they culturally assimilate (Triandafyllidou, 2001).

Several interviewees further indicated an institutional unresponsiveness to immigrants' needs beyond the individual case, which they related to structurally induced constraints, such as weakly institutionalised diversity policies within employment administrations (e.g., bureaucrat interviews 2, 11, 28, 35). In that regard, job centre representatives talked about not having the means to overcome language barriers. They reported feeling ill-equipped to address the challenges that could arise from migration-related diversity. Some job centre respondents equally highlighted their discomfort in conveying legally sensitive matters in a foreign language within which they may not be very well-versed (field notes at a local job centre). Furthermore, interviewees from both inside and outside the job centre noted that, on an informal level, the institutional commitment to diversity lacked behind (bureaucrat interviews 11, 28, 35; key informant interview 11). Although local institutions had started implementing the Federal Employment Agency's diversity strategy of 2007, which marked a formal commitment to diversity, respondents considered related changes in administrative procedures in practice to have remained incidental and superficial thus far (Ratzmann, 2018). An illustrative example is the translation hotline that individual social administrators could call when interacting with claimants unable to converse in German. Observations from the field showed that its existence remained largely unknown at street-level, and if known, not taken up (from field notes at job centres in Berlin, civil society roundtables, and practitioners' meetings).

In short, administrative claims-processing that encompassed some form of language discrimination may be related to two commonly interrelated factors: individual attitudes on a claimant's deservingness, which could motivate social administrators to disregard legal and administrative provisions, and a structurally-induced lack of intercultural awareness, which could reinforce the former trend. Informal practices of discrimination could arise from the interplay between unawareness of how to accommodate intra-EU migrant claimants' needs on an individual level, as well as a perceived lack of means to adequately address language diversity through the institutional means provided. Yet some differences prevailed depending on the job centre studied, with some local institutions appearing more attuned to language needs than others, offering translations of some key documents for claiming in select European languages (Ratzmann, 2019, pp. 164-165).

Additionally, fieldwork revealed the role of erroneous application of administrative guidelines and the legal framework on intra-EU citizens' entitlements. As one administrator stated (field notes from a local job centre), "it is insane how many exceptions there are in the legal framework. It is very ambiguous." A feeling of loss about the myriad of legal rules, administrative guidelines, and court rulings, which all had to be considered when assessing an intra-EU citizen's claim appeared to prevail in several job centres. In the words of a benefits clerk (field notes from a local job centre), "EU citizens are among the most difficult claimant groups, because their 
cases are very complicated to process." The legal complexity of assessing an intra-EU migrant citizen's claim could result in an inadequate application of discretion, or superficial treatment of cases. As a further compounding effect, I noted that barriers to access could be impacted by informal practices of formulaic equality and standardised equal treatment, in other words, of applying the same rules and treatment to every benefit applicant or recipient independent of the diverging needs and circumstances (bureaucrat interviews 3, 23, 24). As this social administrator's argument exemplifies, such a practice appears to be tied to ideas of individual fairness and a structural unawareness of migrants' diverse challenges as newcomers to a society which has perennially declared itself a non-immigration country:

I treat every client the same, I take it fairly literally. Thus, I don't experience any moral conflicts. I treat all my clients the same, independent of how I perceive them, nice or not nice, whether I understand them or not. (bureaucrat interview 30)

Serving each claimant in a similar manner may engender equity in treatment but not in outcome, as diverse claimant groups have differential needs to be served, including their different capabilities to communicate in German.

The qualitative interviews also revealed how claimsprocessing could transpire into rationing access, parking, and rule adaption, which are typical coping strategies of local bureaucracies to resist work and managerial pressures (see Brodkin, 2013). Interviews showed how parking techniques appeared to be related to case complexity. Intra-EU citizens' case files were often subject to parking because their cases were complex to process, often due to ambivalent legal entitlements and potential communicative difficulties with claimants to clarify circumstances (bureaucrat interviews 5, 30; key informant interview 23). Administrators sometimes turned away benefits claimants in need simply to protect themselves from additional or unpleasant work (e.g., bureaucrat interview 13). As local bureaucrats described themselves, pushing hard-to-serve claimants out of sight helped them to cope with what they described as unmanageable workloads of 600 to 900 cases per administrator, referencing 250 to 300 cases as a manageable yardstick (bureaucrat interviews 5, 14, 15, 20, 47). Job centre respondents alluded to how performance measurement principles of efficiency and quantity could counteract individualised processing of claims, not taking differential needs and circumstances into account (bureaucrat interviews 3, 5, 29, 31). Performance control could instead produce adverse displacement effects, i.e., the rejection or delay of time-consuming cases (bureaucrat interviews 7, 13, 12, 21).

Finally, the findings point to compounding effects between the interpersonal and the institutional, as individual discriminatory attitudes could become reinforced through mistranslations (e.g., bureaucrat interviews 3, $23,28)$. Instances of miscommunication, when claimants' insufficient German language skills prevent both parties from clarifying potential misunderstandings, could activate stereotyped representations, such as the trope of social tourism (field notes from local job centres; also Ratzmann, 2019, pp. 157-158). An episode reported by a social lawyer I interviewed is illustrative in this regard (key informant interview 26). He explained how implicit cultural expectations about language proficiency in German can become intertwined with stereotyped representations of some EU national groups:

When people hear Bulgarian, they often think: "Ah, Bulgarian." And only when he or she speaks in fluent German...[do] they rethink and reorient their perceptions.

Put differently, administrative exclusion could arise from a communication gap between job centre staff and EU migrant claimants, as decisions may be based on incomplete information or false premises. Such a gap could be widened by the often complicated and complex linguistic terms public administrators tend to rely on. In the words of one of my foreign language respondents:

It is somewhat about how things are communicated to you. There is always a kind of a mismatch, or a misunderstanding, or a miscommunication. That tension, or frustration, that happens because you can't speak the same language. (claimant interview 2)

Communicative problems could be exacerbated by an implicit and insufficient appreciation of EU migrant claimants' needs as newcomers to German society. Even though an administrative framework on language policy regarding intra-EU citizens exists, it seems to remain largely unapplied in local claims-processing. Such implementation lags and erroneous application of administrative frameworks and institutional strategies on language diversity influence the ways in which street-level bureaucrats exercise their informal discretion around accommodating language needs or not. In other words, discretion enables some of the discriminatory treatment identified in this article. As a result, claimants' ability to converse in German becomes an instrument of strategic exclusion from de facto benefit receipt, whether intended or not.

\section{Discussion}

The findings presented here highlight the relationship between individual strategies of claims-processing and their institutional embeddedness, i.e., the meso-level institutional forces that impact administrative routines in a systematic manner and may lead to administrative exclusion of some intra-EU migrant claimant groups. Compared to literature on discrimination focusing on the interpersonal interaction dynamics that create unequal 
opportunities structures (Beigang et al., 2016), part of the original contribution of this article is this exploration of the entanglements between legal entitlements as rights on paper, and de facto access structured by the institutional setting within which local social bureaucrats implement policies. Hence, while the practices described in part one of the analysis remain agency-based, the second part illustrates how the institutional environment shapes individual decisions, tied to processing routines and organisational blind spots, which reinforce or mediate individual attitudes.

In sum, German job centres, like their Austrian equivalents (Scheibelhofer et al., 2021), continuously present themselves as mostly monolingual organisations in practice, resulting in intra-EU migrants' de facto access to social benefits and services being impacted by claimants' knowledge of the German language. Both administrators and claimants tended to portray German non-proficiency as an individual deficiency of the respective foreign claimant, rather than as a structural issue of the institution. Such a lens evokes ideas of cultural assimilation, of how cultural exclusion or "insiderness" is produced. As such, foreign claimant interviewees' accounts suggested that they internalised the implicit demand for German knowledge as a prerequisite to claim, interpreting potential instances of language discrimination as their fault and "not as a problem of the system" (claimant interview 2). In the words of one of the interviewed EU claimants, language remains "the means through which you get integrated" (claimant interviews 5, 7). Consequently, language is not simply a functional element of communication, but it also turned into a signifier of willingness to integrate. In this way, job centre staff often made those not able to converse in German feel they were "not belonging." In more theoretical writings (e.g., Fanon \& Philcox, 2004), it has been argued that such (internalised) demands for language acquisition could be interpreted as a form of racism.

Interestingly, the case of intra-EU migrants' potential experiences of language discrimination could be contrasted with those of refugee claimants. Some job centre respondents alluded to a stronger willingness to accommodate linguistic deficiencies if claimants "fled from a country at war," compared to EU citizens whom they would categorise as voluntary migrants (e.g., bureaucrat interview 45). Here, ideas of deservingness became conditioned by migrants' control over their situation (see van Oorschot, 2008). Such logic could equally be observed at an institutional level: the job centres studied for this research appeared to implement a multilingual service culture more systematically for refugee claimants. This could involve funding made available to hire interpreters for the languages spoken in refugees' countries of origin, but not for other migrant claimants.

Overall, the findings presented here allow for conclusions to be drawn on how informally institutionalised practices of handling linguistic diversity at street-level may contribute to defining the boundaries of de facto social citizenship in practice, and who can access entitlements to social benefits and services. Resonating with Lamont and Molnár's (2002) work, the symbolic boundaries drawn between linguistic insiders and outsiders could materially manifest themselves as unequal access to welfare resources. Put differently, the observed selective and incidental implementation of language policies could produce inconsistencies in social administrators' application of administrative and legal guidelines during claims-processing, which could translate into denial of benefit receipt in practice. As a side effect, such inconsistencies led intra-EU claimants to grapple with ambiguous rules and regulations, potentially causing them to abandon their claim.

\section{Conclusion}

This article explored how institutionalised practices of claims-processing at street-level can lead to barriers in access to and de facto exclusions of some EU migrant citizens with legal entitlements to social benefits. To that end, the article first explored local administrative practices of inclusion and exclusion based on claimants' ability to converse in German. The research then explained the occurrence of such practices through the interplay between individual claims-processing routines and implementation constraints, showing how individual attitudes can become reinforced through the institutional environment. As such, the findings illustrate how practices of individual discrimination can emerge through institutional constraints of street-level work, which may force administrators to exclude applicants from benefit receipt for reasons other than their individual attitudes. Due to the described pressures of administrative work, the current claiming system creates added costs for street-level bureaucrats to act on preferences of inclusion.

Overall, the analysis highlights the discrepancy between EU migrants' formal entitlements in principle, and their substantive rights in practice. The findings provide suggestive evidence to explain German social bureaucracy's incapacity to handle linguistically-diverse groups of claimants. While local social bureaucrats may not discriminate intentionally, their day-to-day practices can bring about adverse effects for intra-EU migrant claimants. Knowledge of local language not only facilitates their manoeuvring within German society and bureaucracy in practice but also symbolically allows them "to belong." Hence, while certain inequalities in treatment may be justifiable from an administrator's point of view as coping strategies, such de facto displacement effects raise the moral question of what sorts of disadvantage state administrations should pro-actively counterbalance. Should granting social rights to foreign claimants go hand-in-hand with securing equal access to claiming rights in practice? Hence, should it be a government responsibility to offset the diverse needs and circumstances of claimants? 


\section{Acknowledgments}

I am indebted to my interviewees who made this research possible. I would also like to extend a special thanks to my PhD supervisors Harley Dean and Isabel Shutes, at the London School of Economics, and the Leverhulme Trust UK, whose funding made this research project possible. Finally, this article would not have seen the light of day without the support of Sabrina Zajak and her valuable feedback, as well as Andrea Blanchard in the final stage of this publication.

\section{Conflict of Interests}

The author declares no conflict of interests.

\section{References}

Alpes, M. J., \& Spire, A. (2014). Dealing with law in migration control. The powers of street-level bureaucrats at French consulates. Social \& Legal Studies, 23(2), 261-274.

Bach, T., \& Wegrich, K. (2018). Blind spots, biased attention, and the politics of non-coordination. In T. Bach \& K. Wegrich (Eds.), The blind spots of public bureaucracy and the politics of non-coordination (pp. 3-28). Palgrave Macmillan.

BAGFW. (2021). Auswertung der Umfrage zu Praxiserfahrungen der Mitarbeitenden in der Beratung: Schwierigkeiten von EU-Bürgerinnen und EU-Bürgern in der Durchsetzung von Leistungsansprüchen [Survey results of social counsellors' experiences: EU citizens' difficulties to realise their legal entitlements in practice]. Bundesarbeitsgemeinschaft der Freien Wohlfahrtspflege.

Beigang, S., Fetz, C., Kalkum, D., \& Otto, M. (2016). Diskriminierungserfahrungen in Deutschland. Ergebnisse einer Repräsentativ- und Betroffenenumfrage [Experiences of discrimination in Germany. Results from a representative survey of those concerned]. Nomos.

Brodkin, E. Z. (2013). Street-level organisations and the welfare state. In E. Brodkin \& G. Marston (Eds.), Work and the welfare state. Street-level organizations and workfare politics (pp. 17-34). Georgetown University Press.

Brodkin, E. Z., \& Majmundar, M. (2010). Administrative exclusion. Organizations and the hidden costs of welfare claiming. Journal of Public Administration Research and Theory, 20(4), 827-848.

Brussig, M., Frings, D., \& Kirsch, J. (2017). Diskriminierungsrisiken in der öffentlichen Arbeitsvermittlung [Risks of discrimination in public employment administrations]. Nomos.

Bundesagentur für Arbeit. (2011). Inanspruchnahme von Dolmetscher- und Übersetzungsdiensten sowie Regelungen für den Einsatz und die Verwendung von Dienstausweisen [Usage of translation and interpretation services and regulations for the use of work
IDs] (HEGA 05/11-08).

Council Directive 2000/43/EC of 29 June 2000 implementing the principle of equal treatment between persons irrespective of racial or ethnic origin. Official Journal of the European Communities, L 180.

Crotty, M. (1998). The foundations of social research. Meaning and perspective in the research process. SAGE.

Dittmar, V. (2016). Arbeitsmarktintegration für Migranten fördern. Potenziale der Jobcenter [Advancing labour market integration of migrants. The potential of job centres]. Wbv Verlag, Bertelsmann.

Dubois, V. (2010). The bureaucrat and the poor. Encounters in French welfare offices. Ashgate.

Dwyer, P., Scullion, L., Jones, K., \& Stewart, A. (2019). The impact of conditionality on the welfare rights of EU migrants in the UK. Policy and Politics, 47(1), 133-150.

Fanon, F., \& Philcox, R. (2004). The wretched of the earth. Grove Press.

Gomolla, M. (2010). Institutionelle Diskriminierung. Neue Zugänge zu einem alten Problem [Institutional discrimination. New avenues of research to an old problem]. In U. Hormel \& A. Scherr (Eds.), Diskriminierung. Grundlagen und Forschungsergebnisse [Discrimination. Basic research findings] (pp. 61-93). Springer.

Gomolla, M., \& Radtke, F.-O. (2009). Institutionelle Diskriminierung: Die Herstellung ethnischer Differenz in der Schule [Institutional discrimination: The emergence of ethnic difference in school settings]. Springer.

Heidenreich, M., \& Rice, D. (2016). Integrating social and employment policies at the local level: Conceptual and empirical challenges. In M. Heidenreich \& D. Rice (Eds.), Integrating social and employment policies in Europe. Active inclusion and challenges for local welfare governance (pp. 16-50). Edward Elgar Publishing.

Holzinger, C. (2019). "We don't worry that much about language": Street-level bureaucracy in the context of linguistic diversity. Journal of Ethnic and Migration Studies, 46(9), 1792-808.

Lamont, M., \& Molnár, V. (2002). The study of boundaries in the social sciences. Annual Review of Sociology, 28(1), 167-195.

Lipsky, M. (1980). Street-Level bureaucracy. Dilemmas of the individual in public services. SAGE.

Maynard-Moody, S., \& Musheno, S. (2003). Cops, teachers, counsellors. Stories from front lines of public service. The University of Michigan Press.

Mill, J. S. (2002). A system of logic. Ratiocinative and inductive; being a connected view of the principles of evidence and the methods of scientific investigation. Pacific University Press. (Original work published 1843)

Perna, R. (2018). Re-bounding EU citizenship from below: Practices of healthcare for "(il)legitimate EU migrants" in Italy. Journal of Ethnic and Migration Studies, 44(5), 829-848. 
Ratzmann, N. (2018). Mind the gap: Vielfaltspolitik der deutschen Arbeitsverwaltung. Impulse zur Vielfalt [Diversity policies in German employment administration. Impulses for diversity]. Deutsch Plus, Initiative für eine plurale Republik.

Ratzmann, N. (2019). Caught between the local and the (trans)national: EU citizens at the front-line of German welfare policy [Doctoral dissertation, London School of Economics]. LSE Theses Online. http:// etheses.Ise.ac.uk/3982

Ratzmann, N. (2021). Deserving of social support? Streetlevel bureaucrats' decisions on EU migrants' benefit claims in Germany. Social Policy and Society, 20(3), 509-520.

Scharpf, F. (2000). Institutions in comparative policy research. Comparative Political Studies, 33(6/7), 762-790.

Scheibelhofer, E., \& Holzinger, C. (2018). “Damn it, I am a miserable Eastern European in the eyes of the administrator": EU migrants' experiences with (transnational) social security. Social Inclusion, 6(3), 201-209.

Scheibelhofer, E., Holzinger, C., \& Draxl, A.-K. (2021). Linguistic diversity as a challenge for street-level bureaucrats in a monolingually-oriented organisation. Social Inclusion, 9(1), 24-34.

Schweitzer, R. (2019). Health care versus border care: Justification and hypocrisy in the multilevel negotiation of irregular migrants' access to fundamental rights and services. Journal of Immigrant \& Refugee Studies, 17(1), 61-76.

Shutes, I. (2016). Work-related conditionality and the access to social benefits of national citizens, EU and non-EU citizens. Journal of Social Policy, 45(4), 691-707.

Shutes, I., \& Walker, S. (2017). Gender and free movement. EU migrant women's access to residence and social rights in the UK. Journal of Ethnic and Migration Studies, 44(1), 137-153.

Soss, J. (2006). Talking our way to meaningful explanations. A practice-centered view of interviewing for interpretative research. In D. Yanow \& P. SchwartzShea (Eds.), Interpretation and method. Empirical research methods and the interpretive turn (pp. 161-181). M. E. Sharpe.

Triandafyllidou, A. (2001). Immigrants and national identity in Europe. Routledge.

Triandafyllidou, A. (2003). Immigration policy implementation in Italy. Organisational culture, identity processes and labour market control. Journal of Ethnic and Migration Studies, 29(2), 257-297.

van Oorschot, W. (2008). Solidarity towards immigrants in European welfare states. International Journal of Social Welfare, 17(1), 3-14.

Wright, M. (2011). Diversity and the imagined community. Immigrant diversity and conceptions of national identity. Political Psychology, 32(5), 837-862.

Yanow, D., \& van der Haar, M. (2013). People out of place: Allochthony and autochthony in the Netherlands' identity discourse: Metaphors and categories in action. Journal of International Relations and Development, 16, 227-261.

\section{About the Author}

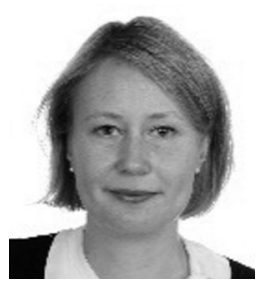

Nora Ratzmann is a post-doctoral researcher with a focus on migration politics and social inequality, whose experience includes assignments at Oxford University, RAND Europe, UNESCO, and the Expert Council of German Foundations for Migration and Integration. She currently holds positions as a research fellow at the German Center for Integration and Migration Research (DeZIM) and Centre for Analysis of Social Exclusion (CASE), LSE. Nora obtained her PhD in social policy from the London School of Economics in 2019. 